\title{
Towards the definition of specialized vessels' model
}

\author{
Rossella Luglietti \\ Politecnico di Milano \\ Via Lambruschini 4b, 20156 \\ Milano, Italy \\ rossella.luglietti@polimi.it \\ Claudio Sassanelli \\ Politecnico di Milano \\ Via Lambruschini 4b, 20156 \\ Milano, Italy \\ Carlos Moyano Martín \\ Centro Tecnologico Naval y del Mar \\ Parque Tecnológico Fuente Álamo, 30320 \\ Fuente Álamo (Murcia), Spain
}

\author{
Stephan Wurst \\ BALance Technology Consulting $\mathrm{GmbH}$ \\ Contrescarpe 33, 28203 \\ Bremen, Germany
}

\author{
Sergio Terzi \\ Politecnico di Milano \\ Via Lambruschini 4b, 20156 \\ Milano, Italy
}

\begin{abstract}
Nowadays, the need of reducing the negative impact of boats during their entire lifecycle is furtherly strengthened by the increasingly businesses and services carried out within the marine space. In this context, several regulations and research streams are aimed to cope with this need, leading to the final challenge to develop more suitable novel specialized vessels. However, in this context, the necessity to evaluate the environmental implications of this novel concept of specialized vessels shall be taken into account at the early design stage. This paper proposes a model for new specialized vessels, built on both theoretical and practical bases, opening the way to consistently conduct the Life Cycle Assessment (LCA) and Life Cycle Costing (LCC) approach on such complex innovative maritime solutions and hence unleashing further researches in the stream.
\end{abstract}

Keywords-Functional group, Life Cycle Assessment, Vessel, Maritime sector

\section{INTRODUCTION}

The European Commission adopted in 2015 a Circular Economy Package aimed to help European entities and consumers to reach a stronger and circular economy, where resources are used in a sustainable way. Nonetheless, some international regulations were already set regarding emissions from combustion gases in boats. The International Maritime Organization (IMO) ship pollution rules are contained in the "International Convention on the Prevention of Pollution from Ships", known as MARPOL 73/78. MARPOL Annex VI "Regulations for the Prevention of Air Pollution from Ships" sets limits on NOx and SOx emissions from ship exhausts and prohibits deliberate emissions of ozone depleting substances.

The International Maritime Organization (IMO) was involved in developing technical and operational measures to enhance onboard environmental efficiency. These measures included the Energy Efficiency Design Index (EEDI), the Energy Efficiency Operational Indicator (EEOI), and the Ship
Energy Efficiency Management Plan (SEEMP) [1]. Previous studies in marine transport research focused on energy consumption and/or emissions, marine diesel engines, operational strategies, innovative technologies for efficiency improvement, alternative system designs and other approaches related to decision making, and economics [2]. The EU Regulation 2015/757 considers the CO2 emissions from ships of more than 5000 GT. An annual report of these emissions is provided, to ease the performance of carbon footprint of boats.

The need of reducing the negative impact of boats during their entire lifecycle is furtherly strengthened by the increasingly businesses and services carried out within the marine space (e.g. aquaculture, renewable energy, environmental monitoring, accident response and clean up) [3]. Since inappropriate vessels can increase costs, resulting ineffective for the task concerned and impacting in a negative way along their entire life cycle, the challenge is to develop novel specialized vessel concepts which are economically viable and environmentally friendly and which will more effectively serve coastal activities.

Under this scenario, the need to evaluate the environmental implications of this novel concept of specialized vessels shall be taken into account at the early design stage. The environmental impacts shall cover the entire vessel life cycle, in order to cover the environmental target required by the Design for Environment methodology rules. The Design for Environment is one of the tool chosen to assess this novel specialized vessel. The first research question we have to present is: Are these novel specialized vessels environmental sustainable?

Before to answer to this question, the description of this novel vessel shall be carried out. This research aims to define the right methodology to describe the specialized vessels, which will be the basis to apply the environmental assessment methodology. The result of this research is a theoretical structure 
model, which help the researcher on characterizing the product in order to carry out the environmental impact results through the life cycle.

In order to achieve this objective, the paper is structured as following. In particular, chapter II presents the research context reporting the methodologies available in literature to perform environmental assessment, highlighting the chosen methodology able to answer to the research question. Chapter III describes the method and process through which this research has been conducted. Chapter IV presents the main result of the work, the specialized vessel model, starting from the business case description, then explaining how its concept has been conceived and finally presenting its evolution up to the validated vessel model. Lastly, chapter $\mathrm{V}$ presents the discussion and chapter VI concludes the paper also reporting the next steps of this research stream.

\section{RESEARCH CONTEXT}

The main purpose of this chapter is a full review of the current methodologies available to carry out the environmental dimension within the product life cycle (or specific steps). The review helps the identification of the right methodology to answer to the research question.

The following tool has been identified:

- Energy and resource efficiency: Energy efficiency is a generic term, and there is no one unequivocal quantitative measure of energy efficiency. Instead, one must rely on a series of indicators to quantify changes in energy efficiency. In general, energy efficiency refers to using less energy to produce the same amount of services or useful output [4]. The methodological approach evaluates the impacts during the operational phase, including the fuel and resources consumption for vessel operations, including the maintenance needs. This methodology excludes the evaluation of the beginning of life (production and assembly phase), and the end of life (disposal and recycling). The benefits of this methodology is the usage of direct data from the usage phase with little simplifications due to data availability. The limitations could be summarized with the exclusion of life cycle stages, which could have significant impacts among the life cycle. The risk with this methodology is to exclude steps of the life cycle with high impacts. In fact, when calculating energy efficiency indicators, only certain energy inputs are considered, and others are considered to be outside the study's boundary [4].

- Ecological Risk Assessment: Ecological risk assessment evaluates ecological effects caused by human activities such as draining of wetlands or release of chemicals. The term "stressor" is used to describe any chemical, physical, or biological entity that can induce adverse effects on individuals, populations, communities, or ecosystems. Risk assessments are often very narrowly focused on a single chemical at a very specific location (Norton et al. 1993). A limitation of this methodology is that it describes effects on the environment with many details, but it is difficult to understand the global impact of a product.

- Environmental Impact Assessment (EIA): An Environmental Impact Assessment is a formal process used to calculate the environmental consequences (positive or negative) of a plan, policy, program, or project prior the implementation decision, but it is not applicable to products [5].

- Life Cycle Thinking: Life Cycle Thinking [6] is a systematic approach that considers the entire product lifecycle. Part of this approach is followed by two standard methodologies: Life Cycle Assessment (LCA) [7] and Life Cycle Costing (LCC), where the first one focuses on the environmental dimension, and the second one focus on the costs. One of the benefit of this methodology is the whole consideration of life cycle stages, avoiding the problem of excluding impacts related to specific step of the life cycle. The main limitation of this methodology is that information collection related to some lifecycle stages is difficult. The same approach is used by the whole panel of methodology that aims to evaluate the sustainability of products and services through the full life cycle.

Considering the above list of methodologies that can be used to evaluate the environmental impacts, the Life Cycle Thinking has been identified as the valuable methodology to answer the research question. The standardized methodology to evaluate the environmental impacts covering the Life Cycle Thinking approach is the Life Cycle Assessment. Life Cycle Assessment is a structured, comprehensive and international method standardized by the ISO (International standardization Organization) with the guidelines ISO 14040 and 14044 [7]. It quantifies all the relevant emissions and resources consumed, both directly and indirectly, and the related environmental and health impacts and resource depletion issues that are associated with the entire life cycle of any goods or services (in general terms, of a product).

\section{RESEARCH METHOD}

The proposed model for specialized vessels has been conceived, developed and defined following the research method presented in this chapter (Figure 1).

The aim of the first phase of the research has been the concept definition of the specialized vessel model: first, it has been carried out through the analysis and assessment of the Ecoinvent Database, the most important extant international DB used to support the LCA analysis through the software Simapro 8.01: however, it provides data only for modelling traditional boats. Then, based on the findings of this analysis, the functional group approach has been selected and a study of the literature has been performed to fill the detected gaps and understand how to satisfy the Business Cases needs through a scientific and theoretical perspective. As a result, the concept of the model was ready for validation and improvement. Indeed, it has been evaluated by three European shipbuilders previously providing the needs and also by one maritime industry expert (supported by the use of a documentation of a prominent German 
shipbuilding company located at the Weser river in BremenVegesack). Thanks to this phase, some enhancements of the model were proposed and implemented, leading to obtain the final specialized vessel model useful to conduct the LCA analysis for specialized vessels.

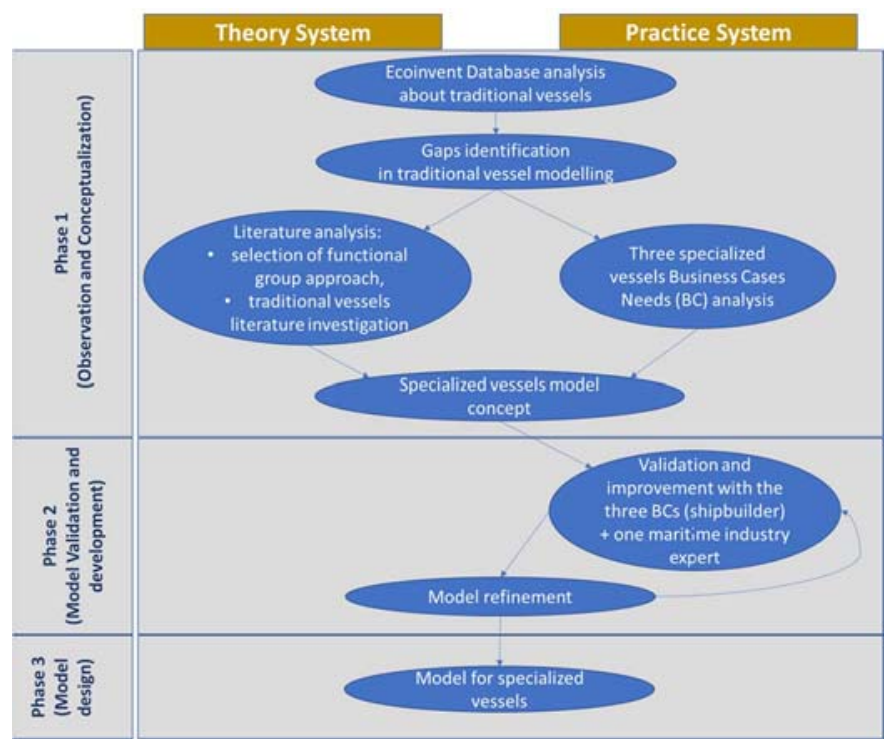

FIGURE 1: RESEARCH METHOD PROCESS

In the next chapter, the model is proposed and its improvements along its development path are described.

\section{SPECIALIZED VESSEL MODEL}

In the following, first the BCs needs deriving from the three shipbuilders are presented (chapter IV-A). Therefore, in chapter IV-B, starting from the gaps detected through the Ecoinvent Database analysis, it is explained how the contributions coming from both theory (literature analysis) and practice (BC shipbuilders needs) have been used to build the model concept for specialized vessels. Finally, in chapter IV-C, the final model for specialized vessels is presented: moreover it is described how the model concept, proposed by the authors at the end of the observation and conceptualization phase, has been validated and improved by the three BCs shipbuilders and a maritime industry sector.

\section{A. Business case description}

The specialized vessel model has been carried out following the needs of three European shipbuilders, one from Norway, one from Spain and the last one from Greece, as described below:

1. Business Case 1: Multiplatform catamaran Survey and Service.

The vessel is mainly designed to serve in the offshore energy and aquaculture facilities, although the vessel is designed in order to be able to give support to other activities involving crew services and surveys such as, for example, marine biotechnology activities. The multi-functionality can be achieved by changing the configuration and distribution of the superstructure during the building phase as well as by implementing different equipment on-board. The first objective of the multi-platform catamaran use case is the successful implementation of an improved propulsion system in terms such as performance and low emissions by means of installing a hybrid system, reducing the environmental impacts.

\section{Business Case 2: Module based high speed patrol boat platform.}

The module-based patrol boat platform allows configurable high speed crafts design for monitoring and control services. The main aim is to create an advanced adaptive platform for four specific market segments enabling customization in order to achieve a higher degree of modularity. By developing a module based patrol boat platform that is configurable, intends to address a series of issues related to the production of patrol vessels for different tasks, which to this day implies new designs and production, such as: high cost development, high cost solutions, high maintenance/running/service costs. All of these aspects are also strictly related to the environmental impacts.

3. Business Case 3: Emergency Response and Recovery Vessel (EERV);

The vessel will incorporate an innovative Integrated Dynamic Position System (DP System) for optimizing the position stability at the desirable $\mathrm{X}, \mathrm{Y}, \mathrm{Z}$ coordinates. The DPS will be combined with the installation of cutting-edge technology to the vessel in order to smooth the different critical operations carried out by the ERRV by means of enhancing security, response capacity and decision-making. The environmental assessment will evaluates if the DPS is also able to reduce the environmental impacts.

The three business cases has been classified considering three different aspects: the application of the specialized vessel, the reasons for carrying out the environmental assessment, the target audience and final, the most important, the intention to implement comparison scenarios (Table 1). These aspects has been considered during the vessel model definition, in order to take into account the main objectives of the three business cases.

TABLE 1: GOAL DEFINITION WITHIN THE THREE VESSELS.

\begin{tabular}{|c|c|c|c|}
\hline Goal definition & $\begin{array}{c}\text { Multiplatform } \\
\text { catamaran }\end{array}$ & $\begin{array}{c}\text { High speed } \\
\text { patrol vessel }\end{array}$ & EERV \\
\hline $\begin{array}{c}\text { Intended } \\
\text { application }\end{array}$ & $\begin{array}{c}\text { Patrol and } \\
\text { security } \\
\text { operators }\end{array}$ & $\begin{array}{c}\text { Coastal } \\
\text { rescue } \\
\text { activities }\end{array}$ & $\begin{array}{c}\text { Service crew } \\
\text { vessel and } \\
\text { multipurpose } \\
\text { survey } \\
\text { vessel }\end{array}$ \\
\hline $\begin{array}{c}\text { Reasons for } \\
\text { carrying out the } \\
\text { study and decision } \\
\text { context }\end{array}$ & $\begin{array}{c}\text { Use the } \\
\text { standardization } \\
\text { and modularity } \\
\text { approach of } \\
\text { the Lean } \\
\text { Design and } \\
\text { real-life data } \\
\text { for fact-based } \\
\text { improved } \\
\text { design }\end{array}$ & $\begin{array}{c}\text { Presence of } \\
\text { electronic } \\
\text { systems and } \\
\text { IoT } \\
\text { connection } \\
\text { and Integrated } \\
\text { Dynamic } \\
\text { Position } \\
\text { System }\end{array}$ & $\begin{array}{c}\text { New transfer } \\
\text { multipurpose } \\
\text { solution } \\
\text { optimized } \\
\text { for Ocean } \\
\text { energy and } \\
\text { Aquaculture } \\
\text { activities }\end{array}$ \\
\hline $\begin{array}{c}\text { Comparison } \\
\text { intended }\end{array}$ & $\begin{array}{c}\text { Series of boat } \\
\text { production to } \\
\text { low cost and } \\
\text { environmental } \\
\text { impacts }\end{array}$ & $\begin{array}{c}\text { Help rescue } \\
\text { operators } \\
\text { during the } \\
\text { ship wreckers } \\
\text { rescuing and }\end{array}$ & $\begin{array}{c}\text { Reduce } \\
\text { operations } \\
\text { costs and } \\
\text { being eco- } \\
\text { friendly }\end{array}$ \\
\hline
\end{tabular}




\begin{tabular}{|c|c|c|c|}
\hline & & $\begin{array}{c}\text { reduce } \\
\text { operative } \\
\text { costs and } \\
\text { environmental } \\
\text { impacts }\end{array}$ & \\
\hline Target audience & $\begin{array}{c}\text { End users and } \\
\text { maritime } \\
\text { operators }\end{array}$ & Service boat & End users \\
\hline
\end{tabular}

\section{B. Building the specialized vessel model concept}

The specialized vessel model concept is a structured model describing the product considering its complexity and functionality.

The preliminary review carried out is the evaluation of Ecoinvent database maritime transport module (ref), where the product and its life cycle has been studied in order to perform the LCA. Almost all the process datasets are transparently documented on the level of unit process for inputs and outputs. Methodological approaches have been applied consistently throughout the entire database content and thus guarantee for a coherent set of inventory data [8].

The Ecoinvent datasets cover data for the water transportation unit processes, where it includes the dataset for the maritime service and the shipbuilding.

The water transportation is modelled for the following vessels [9]:

- transoceanic tanker (average of slow speed engine and steam turbine propulsion);

- transoceanic freight ship (average of slow speed engine and steam turbine propulsion);

- barge tanker (average barge tanker operating on inland waterways);

- barge (average barge operating on inland waterways).

The four vessel models in Ecoinvent are vessels made by steel metal, with different materials and production processes respect to the Lincoln business cases. The water transport includes direct and indirect processes. Ecoinvent classifies the module as direct processes in the vessel operation (during the usage phase) and as indirect processes in the shipbuilding and port facilities (Figure 8). Consequently, the system model "water transport" is divided in three components [9]:

- Ship Operation: contains all processes that are directly connected with the operation of the vessel (energy consumption and maintenance).

- $\quad$ Shipbuilding: contains processes describing the vessel life cycle (excluding the operation). All exchanges and interventions are referred to one vessel.

- Port Infrastructure: comprises the port infrastructure life cycle, including port construction, port operation and maintenance as well as port disposal. All exchanges and interventions are referred to the one port. In addition, for inland shipping, artificial waterways (construction and operation of canals) are modeled.
The dataset module covers with details the technical requirements of ship operation, providing the right methodology to calculate the requirements as reported by the ISO documentations.

Considering the shipbuilding the dataset module includes general information about the main materials, without taking into account the complexity and the functionality of the single components. For this reason, a model, which consider the complexity of a vessel, with different components and level of functionality has been taken into account. Specialized vessels are defined as complex products, considering the fact that they are composed by different components with different level of functionality.

The functional groups analysis has been used as the main methodology able to describe a complex product including components of different functionalities and level of details. These schemes allows us to better comprehend the current state of the art in terms of production technologies, the existing links between different components of a boat and how the collected information of materials and components can be summarized in sub-levels. The same methodology has been used in [10] based on the scheme of Pimmler and Eppinger 1994 [11], Chung et al 2011 [12], Yu et al 2011 [13]. Thanks to these schemes, we setup the main structure of the vessel, and link to each component the list of subcomponents, materials and KPIs. The scientific literature reviewed for vessel sectors provides few examples of functional groups. From the literature, we discovered that also other authors used the same approach. For example, Garbatov et al., 2017 [14] implemented a cost analysis using an approach with 2 different levels, providing the cumulative economic results using the following subsystem: hull structure, equipment and outfitting and machinery. For each group a list of sup components has been identified. In the case of Hull structure, information about the main hull structure, superstructure and deckhouses are collected in terms of materials and costs. BlancoDavis, del Castillo and Zhou, 2014 [15] considers functional level in order to be able to simplify the model during the collecting data phase of LCA. The vessel is broken down into sub-systems; sub-systems are then broken down into system elements and system elements consequently broken down into processes. With regard to the proposed case vessel as a whole, some systems have been included in the assessment, while others have been disregarded.

In the main time, the functional group analysis has been shared to the industrial partners in order to implement a first basis of the specialized vessel model, as reported in Table 2.

TABLE 2: PRELIMINARY CONCEPT OF THE SPECIALIZED VESSEL MODEL

\begin{tabular}{|l|l|}
\hline \multicolumn{1}{|c|}{ Block } & \multicolumn{1}{c|}{ Module } \\
\hline $\begin{array}{l}\text { Drive system and auxiliary } \\
\text { machinery }\end{array}$ & $\begin{array}{l}\text { Propulsion plant and camera of } \\
\text { machines }\end{array}$ \\
\hline Equipment and services & Equipment and services \\
\hline \multirow{2}{*}{ Hull Structure } & Hull \\
\cline { 2 - 2 } & Others \\
\hline \multirow{4}{*}{ Others } & Electric plant \\
\cline { 2 - 2 } & Pressure Vessels \\
\cline { 2 - 2 } & Tanks and piping \\
\cline { 2 - 2 } & Fire Extinguishing Systems \\
\hline
\end{tabular}


This model has been finalized using the cited scientific literature, where Block has been change with Level 1 and Module has been change with Level 2 (Table 3).

TABLE 3: SPECIALIZED VESSEL MODEL CONCEPT.

\begin{tabular}{|c|c|}
\hline Functional Group & Module \\
\hline \multirow{6}{*}{ Hull Structure } & Main hull \\
\hline & Bulkheads \\
\hline & Decks and platforms \\
\hline & Cabin \\
\hline & Superstructure \\
\hline & Foundation \\
\hline \multirow{7}{*}{ Ship equipment } & Anchoring equipment \\
\hline & Mooring equipment \\
\hline & Towing equipment \\
\hline & Rudder \\
\hline & Deck outfitting \\
\hline & Non-propulsion mechanical equipment \\
\hline & Electric system \\
\hline \multirow{4}{*}{$\begin{array}{l}\text { Drive system and auxiliary } \\
\text { machinery }\end{array}$} & Propulsion machinery \\
\hline & Auxiliary machinery \\
\hline & Control system \\
\hline & Other equipment \\
\hline \multirow{4}{*}{ Other } & Ventilation \\
\hline & Sanitary system \\
\hline & Fire protection \\
\hline & Hull system \\
\hline
\end{tabular}

Whit the two first assessment, industrial partners and scientific literature, the specialized vessel model concept has been defined, where the first level is composed by 4 main groups: Hull Structure, Ship equipment, Drive system and auxiliary machinery and Other (a more generic group).

\section{From concept model to validated model}

The final step of the model development process is the validation of the concept in order to have a validated one. Three industrial shipbuilders and one maritime expert have validated the concept of the specialized vessel model.

The maritime expert, through the experience of a prominent German shipbuilding company located at the Weser river in Bremen-Vegesack, provide a technical document to support the vessel model, with three level of components, and in the first level a more generic group called "Ship equipment". The expert validation sheet was incorporated with the industrial shipbuilders feedbacks in order to achieve the validated model.

In the validated specialized vessel model, the first level of functional group includes three main groups (Figure 1):

1. Hull Structure, which includes the main structure of the boat.

2. Ship Equipment, which includes all the equipment of the boat. In [14] this group was divided in a fourth group called "others" which includes all the equipment with additional functionalities. In this work, we decided to incorporate the group "others" in a more generic "ship equipment" group.

3. Drive system and auxiliary machinery, which includes all the propulsion system.

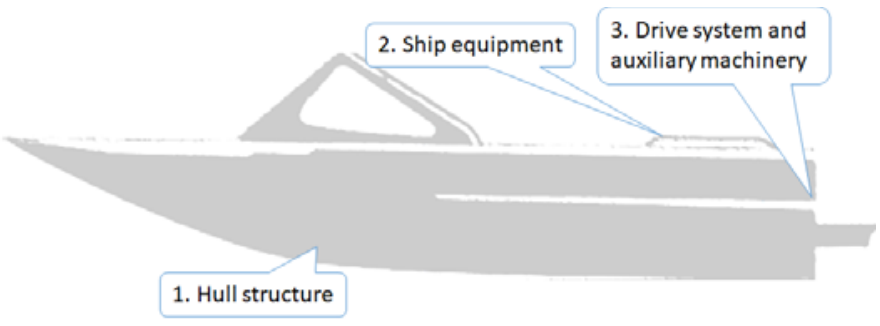

FigURE 2: DEFINITION OF LEVEL 1 OF FUNCTIONAL GROUP.

The second level includes more details about the specific components of each functional group. The Table 4 summarizes the level 2 for each group of the level 1.

Considering the details of the Hull structure, they have been moved in the third level, and the second level has been changed in a more generic body group. The other main difference, between the concept and the validated model, is the subdivision of the auxiliary machinery taking into account the operations: engine operation, ship operation, Cargo Handling and accommodation systems.

TABle 4: Definition of LeVEl 2 of Functional group

\begin{tabular}{|c|c|c|}
\hline \# & Level 1 & Level 2 \\
\hline 1 & HULL STRUCTURE & Body \\
\hline \multirow{9}{*}{2} & \multirow{9}{*}{ SHIP EQUIPMENT } & Steering Gear \\
\hline & & Anchor, Deck Machinery \\
\hline & & $\begin{array}{l}\text { Life Saving Equipment, MARPOL } \\
\text { Equipment }\end{array}$ \\
\hline & & $\begin{array}{l}\text { General Outfitting components for ship } \\
\text { operation }\end{array}$ \\
\hline & & Paintings and coatings \\
\hline & & Cargo Handling Equipment \\
\hline & & Others (Special Cargo Plants) \\
\hline & & Accommodation \\
\hline & & Electrical Plants \\
\hline \multirow{4}{*}{3} & \multirow{4}{*}{$\begin{array}{c}\text { DRIVE SYSTEM AND } \\
\text { AUXILIARY MACHINARY }\end{array}$} & Propulsion, Power Generation \\
\hline & & $\begin{array}{l}\text { Auxiliary engines, Apparatus and } \\
\text { Accessories for Engine Operation } \\
\text { (Seawater cooling, freshwater cooling, } \\
\text { fuel systems, lubricating oil systems, } \\
\text { steam systems, heating systems) }\end{array}$ \\
\hline & & $\begin{array}{l}\text { Auxiliary engines, Apparatus and } \\
\text { Accessories for Ship Operation (ballast } \\
\text { water, fuel tank, firefighting, deck } \\
\text { washing, pressurized air, tank heating } \\
\text { etc) }\end{array}$ \\
\hline & & $\begin{array}{l}\text { Auxiliary engines, Apparatus and } \\
\text { Accessories for Cargo Handling (Cargo }\end{array}$ \\
\hline
\end{tabular}




\begin{tabular}{|l|l|}
\hline \multirow{5}{|l|}{} & $\begin{array}{l}\text { hold heating and cooling, cargo pumps, } \\
\text { conveyer and suckers, Inert gas plants, } \\
\text { tank cleaning, tank heating etc) }\end{array}$ \\
\cline { 4 - 4 } & $\begin{array}{l}\text { Auxiliary engines, Apparatus and } \\
\text { Accessories for Accommodation } \\
\text { Systems (Drinking Water, Sanitation } \\
\text { hot/cold water/sewage, HVAC, Waste } \\
\text { Disposal, swimming pool technology, } \\
\text { etc) }\end{array}$ \\
\hline & Engine Room, Outfitting \\
\hline & Special Plants Ship Operation \\
\hline
\end{tabular}

Finally, thanks to the expert review, the third level has been used to highlight the main subcomponents that will be used for the mass balance of each business case. For each Level 1 of the block analysis detailed components of Level 3 has been identified in order to be comparable with the three business cases during the data collection. Table 5 shows the relation between Level 2 and Level 3 of the Hull structure. Level 2 was defined with a unique group for the vessel body. In Level 3 six main subcomponents with different functions and characteristics has been identified.

TABle 5: Definition of LeVel 3 of Functional group For Hull STRUCTURE OF LEVEL 1.

\begin{tabular}{|c|c|c|}
\hline Level 1 & Level 2 & Level 3 \\
\hline \multirow{4}{*}{1} & \multirow{4}{*}{ Body } & Hull \\
\cline { 3 - 3 } & & Deck \\
& & Roof \\
& & Bulkhead \\
& & Super-structure \\
& & Foundations \\
\hline
\end{tabular}

Table 6 reports the detailed of Level 3 related to the ship equipment Level 1 group. Level 2 has been identified considering the related function of the equipment.

TABle 6: Definition of LeVEl 3 of FunCtional GROUP FOR ShiP EQUIPMENT OF LEVEL 1.

\begin{tabular}{|c|c|c|}
\hline Level 1 & Level 2 & Level 3 \\
\hline \multirow{17}{*}{2} & \multirow{3}{*}{ Steering Gear } & Steering gear \\
\hline & & Rudder \\
\hline & & Accessories \\
\hline & \multirow{4}{*}{$\begin{array}{l}\text { Anchor, Deck } \\
\text { Machinery }\end{array}$} & Anchor and chain \\
\hline & & Winches \\
\hline & & Mooring equipment \\
\hline & & Ropes and accessories \\
\hline & \multirow{5}{*}{$\begin{array}{l}\text { Life Saving } \\
\text { Equipment, } \\
\text { MARPOL } \\
\text { Equipment }\end{array}$} & Life boats \\
\hline & & Davits, cranes and ramps \\
\hline & & Life rafts \\
\hline & & Others \\
\hline & & MARPOL equipment \\
\hline & \multirow{5}{*}{$\begin{array}{l}\text { General } \\
\text { outfitting } \\
\text { components for } \\
\text { ship operation }\end{array}$} & Signal masts \\
\hline & & Nautical accessories/bridge equipment \\
\hline & & $\begin{array}{l}\text { Stairs, ladders, catwalks, railings (not } \\
\text { accommodation and engine room) }\end{array}$ \\
\hline & & $\begin{array}{l}\text { Openings and closures (e.g. doors, shutters, } \\
\text { fire doors) }\end{array}$ \\
\hline & & Others \\
\hline
\end{tabular}

\begin{tabular}{|c|c|c|}
\hline Level 1 & Level 2 & Level 3 \\
\hline & \multirow{2}{*}{$\begin{array}{l}\text { Paintings and } \\
\text { coatings }\end{array}$} & $\begin{array}{l}\text { Paintings (e.g. hull, decks, cargo holds, } \\
\text { engine room, accommodation) }\end{array}$ \\
\hline & & Coatings (e.g. tanks, anodes) \\
\hline & \multirow{7}{*}{$\begin{array}{l}\text { Cargo handling } \\
\text { equipment }\end{array}$} & Cranes, sucker, conveyors and cargo lift \\
\hline & & Hatch covers \\
\hline & & Ro-ro doors and ramps, trailer lifts \\
\hline & & Cargo hold outfitting and fittings \\
\hline & & Cargo hold insulation \\
\hline & & HVAC for cargo holds \\
\hline & & $\begin{array}{l}\mathrm{CO} 2 \text {, portable firefighting equipment and } \\
\text { accessories }\end{array}$ \\
\hline & \multirow{5}{*}{$\begin{array}{l}\text { Others (special } \\
\text { cargo plants) }\end{array}$} & LNG/LPG plants \\
\hline & & Fishing vessel equipment \\
\hline & & Special equipment for dredgers \\
\hline & & Special equipment for docks \\
\hline & & Specific services \\
\hline & \multirow{9}{*}{ Accommodation } & Pre-prepared cabins \\
\hline & & Doors and windows \\
\hline & & Walls, sea links and coverings \\
\hline & & $\begin{array}{l}\text { Floor coverings, carpets, deck house } \\
\text { insulation }\end{array}$ \\
\hline & & Staircases, railings, lifts \\
\hline & & Accommodation HAVC \\
\hline & & $\begin{array}{l}\text { Sanitary rooms, swimming pool equipment } \\
\text { and accessories }\end{array}$ \\
\hline & & $\begin{array}{l}\text { Equipment for pantry, bar, restaurant, food } \\
\text { storage, laundry }\end{array}$ \\
\hline & & Meubles and decoration \\
\hline & \multirow{9}{*}{ Electrical plants } & $\begin{array}{l}\text { Main plants, generators, batteries, } \\
\text { switchboards etc. }\end{array}$ \\
\hline & & Cable trays, cables, fittings \\
\hline & & E-engines \\
\hline & & $\begin{array}{l}\text { Lighting (all rooms and decks), electrical } \\
\text { heating }\end{array}$ \\
\hline & & $\begin{array}{l}\text { Alarm and control systems (ship } \\
\text { automation, remote engine control, } \\
\text { monitoring, healing, cargo control etc. }\end{array}$ \\
\hline & & Communication systems \\
\hline & & $\begin{array}{l}\text { Nautical equipment (compass, radar, log, } \\
\text { decca, automatic sea charts, wheather } \\
\text { plotter) }\end{array}$ \\
\hline & & Navigational lighting \\
\hline & & $\begin{array}{l}\text { Entertainment systems (e.g. audio, video, } \\
\text { cinema, theater, meeting rooms) }\end{array}$ \\
\hline
\end{tabular}

Table 7 reports the connection between the drive system and auxiliary machinery of Level 1 and the final sub-components of Level 3. For each auxiliary machinery, a detailed list of functional components is reported.

TABLE 7: DEFINITION OF LEVEL 3 OF FUNCTIONAL GROUP FOR DRIVE SYSTEM AND AUXILIARY MACHINERY OF LEVEL 1.

\begin{tabular}{|l|l|l|}
\hline Level 1 & \multicolumn{1}{|c|}{ Level 2 } & \multicolumn{1}{|c|}{ Level 3 } \\
\hline \multirow{4}{*}{3} & \multirow{4}{*}{$\begin{array}{l}\text { Propulsion and } \\
\text { power generation }\end{array}$} & Diesel engine \\
& & Electric engine \\
& & Boiler and steam turbine \\
\cline { 3 - 3 } & & Gas turbine \\
\cline { 3 - 3 } & & Gears and couplings \\
\cline { 3 - 3 } & & Propeller \\
\cline { 3 - 3 } & & Exhaust system \\
\cline { 3 - 3 } & & Shaft and bearings and accessories \\
\hline
\end{tabular}




\begin{tabular}{|c|c|c|}
\hline Level 1 & Level 2 & Level 3 \\
\hline & & Auxiliary engines (diesel) \\
\hline & & Auxiliary boilers \\
\hline & & Interceptor \\
\hline & \multirow{9}{*}{$\begin{array}{l}\text { Auxiliary engines, } \\
\text { apparatus and } \\
\text { accessories for } \\
\text { engine operation } \\
\text { (seawater cooling, } \\
\text { freshwater cooling, } \\
\text { fuel systems, } \\
\text { lubricating oil } \\
\text { systems, steam } \\
\text { systems, heating } \\
\text { systems) }\end{array}$} & Separators \\
\hline & & Pumps \\
\hline & & Heat exchangers, coolers, condensers \\
\hline & & Filters \\
\hline & & Loose tanks \\
\hline & & Fittings (valves etc.) \\
\hline & & Silencers \\
\hline & & Ventilation \\
\hline & & Others \\
\hline & \multirow{8}{*}{$\begin{array}{l}\text { Auxiliary engines, } \\
\text { apparatus and } \\
\text { accessories for ship } \\
\text { operation (ballast } \\
\text { water, fuel tank, } \\
\text { firefighting, deck } \\
\text { washing, pressurized } \\
\text { air, tank heating) }\end{array}$} & System aggregates \\
\hline & & Pumps \\
\hline & & Heat exchangers, coolers, condensers \\
\hline & & Filters \\
\hline & & Piping \\
\hline & & Fittings (valves etc.) \\
\hline & & Firefighting system \\
\hline & & Others \\
\hline & \multirow{5}{*}{$\begin{array}{l}\text { Auxiliary engines, } \\
\text { apparatus and } \\
\text { accessories for cargo } \\
\text { handling (cargo hold } \\
\text { heating and cooling, } \\
\text { cargo pumps, } \\
\text { conveyer and } \\
\text { suckers, inert gas } \\
\text { plants, tank cleaning, } \\
\text { tank heating) }\end{array}$} & System aggregates \\
\hline & & Pumps \\
\hline & & Heat exchangers, cargo preheater \\
\hline & & Ventilators, air handling \\
\hline & & Fittings (valves etc.) \\
\hline & \multirow{5}{*}{$\begin{array}{l}\text { Auxiliary engines, } \\
\text { apparatus and } \\
\text { accessories for } \\
\text { accommodation } \\
\text { systems (drinking } \\
\text { water, sanitation } \\
\text { hot/cold } \\
\text { water/sewage, } \\
\text { HVAC, waste } \\
\text { disposal, swimming } \\
\text { pool technology) }\end{array}$} & System aggregates \\
\hline & & Pumps \\
\hline & & Heat exchangers, cargo preheater \\
\hline & & Ventilators, air handling \\
\hline & & Fittings (valves etc.) \\
\hline & \multirow{5}{*}{$\begin{array}{l}\text { Engine room, } \\
\text { outfitting }\end{array}$} & $\begin{array}{l}\text { Hydraulic and pneumatic control and } \\
\text { display systems for ship operation }\end{array}$ \\
\hline & & $\begin{array}{l}\text { Pipe insulation and engine room } \\
\text { insulation }\end{array}$ \\
\hline & & $\begin{array}{l}\text { Engine room outfitting (staircases, } \\
\text { ladders, railings, walkways) }\end{array}$ \\
\hline & & $\begin{array}{l}\text { Cranes, tracks etc., workshop outfitting } \\
\text { and accessories }\end{array}$ \\
\hline & & $\begin{array}{l}\text { HVAC for engine rooms and } \\
\text { workshops }\end{array}$ \\
\hline & \multirow{3}{*}{$\begin{array}{l}\text { Special plants ship } \\
\text { operation }\end{array}$} & Thrusters, special rudders \\
\hline & & Roll-damping, anti-heeling systems \\
\hline & & Active stabilisers \\
\hline
\end{tabular}

\section{DISCUSSION}

Based on the result obtained with this research, some relevant points can be raised. First of all, the model for specialized boats have been obtained through a development process involving both the state of the art from the literature and the state of practice from the industry side. Indeed, starting from the assessment of a DB used for conducting practical LCA studies, also literature articles have been selected and used. This has been done mainly because the Ecoinvent DB refers to traditional boats, resulting not exhaustive to develop a model for specialized vessels: it focuses more on the materials typically used in the industry, neglecting the precise composition of the vessels and thus also its complexity. Because of this, in this step, in order to be able to adequately manage complexity, the functional group approach was selected as reference to build the concept of the model enabling to precisely define the structure of the boat and of its components.

Furthermore, the model concept, shared with three shipbuilders and one industry expert, was improved: the functional groups proposed (i.e. Hull Structure, Ship equipment, Drive system and auxiliary machinery, and Other) were indeed modified and aggregated in 3 main categories since the group Other were misleading and it was possible to split its components among the other three.

\section{CONCLUSION}

The paper aimed to define and propose a specialized vessel model, which is for specialized vessels. This will constitute the basis to characterize a complex product, such as specialized vessels, before implementing the Life Cycle Assessment (LCA) methodology. Thanks to the process development within the research context, method explained in chapter III, we obtainobtained a validated model, with a main : its concept has been built based on the extant knowledge on traditional vessels, deriving from both a practice context, the Ecoinvent Database, and a theoretical one, the scientific literature, and with a validated model based on . The concept has been also enriched and triangulated with the needs catered by three shipbuilders and aiming to deliver new specialized vessels. Furthermore, after a validation performed by the three shipbuilders and a maritime industry expert., the model has been improved and better defined. Thanks to the validation this process, the result, the obtained model for specialized vessels opens the room for new researches, studies and assessment: indeed, it can be applied on different heterogeneous business cases in order to implement environmental and costs assessment cost assessments based on Life Cycle Thinking approach.

As anticipated in the first chapter of the paper, the research question is about the deals with how to operate an evaluation of environmental impacts of these when novel specialized vessels. are needed to be used to be able to adequately reply to the trends and needs dictated by environmental, performance and economic issues. For this reason, the this research stream envisions as next activities will be main activity the implementation of the Life Cycle Assessment standardized methodology, following its four main phases: 1) goal and scope definition, 2) Life Cycle Inventory, 3) Life Cycle Impact Assessment, 4) life cycle interpretation. The first step will be to define three functional requirements: Functional Unit, System Boundaries and KPIs setting. A full literature review on LCA applied at the vessel sector will be needed and performed to study the above requirements. Finally further LCA application at the vessel sector and shipbuilding system will support the theoretical concept. 


\section{ACKNOWLEDGMENT}

The content of this paper is based on the LINCOLN project (EU H2020 727982) that is currently under development (www.lincolnproject.eu). We wish to express our deep gratitude to all LINCOLN partners.

\section{REFERENCES}

[1] E. Blanco-Davis and P. Zhou, "Life Cycle Assessment as a complementary utility to regulatory measures of shipping energy efficiency," Ocean Eng., vol. 128, no. September, pp. 94-104, Dec. 2016.

[2] J. Ling-chin and A. P. Roskilly, "Ling-Chin J , Roskilly AP . A comparative life cycle assessment of marine power systems . Energy Conversion and Management 2016, 127, 477-493 Copyright : DOI link to article: Date deposited: A comparative life cycle assessment of marine power systems," Energy Convers. Manag., pp. 477-493, 2016.

[3] European Commission, "Report on the Blue Growth Strategy: Towards more sustainable growth and jobs in the blue economy," SWD/2017/128 Final, pp. 1-62, 2017.

[4] M. G. Patterson, "What is energy efficiency?," Energy Policy, vol. 24, no. 5, pp. 377-390, May 1996.

[5] International Institute for Environment and Development, "Environmental impact assessment ( EIA )," no. October, 2005.

[6] European Commission -- Joint Research Centre -- Institute for Environment and Sustainability, International Reference Life Cycle Data System (ILCD) Handbook -- General guide for Life Cycle Assessment - Detailed guidance. 2010.
[7] ISO 14044, Environmental management - Life cycle assessment Requirements and guidelines. 2008.

[8] R. Frischknecht et al., "The ecoinvent Database: Overview and Methodological Framework (7 pp),” Int. J. Life Cycle Assess., vol. 10, no. 1, pp. 3-9, 2005.

[9] M. Spielmann, C. Bauer, R. Dones, and M. Tuchschmid, "Transport Services," e- coinvent Rep. No. 14. Swiss Cent. Life Cycle Invent., no. 14, p. 237, 2007.

[10] D. Cerri, R. Luglietti, P. Rosa, and S. Terzi, "Lifecycle Optimization in the Refrigeration Industry: A Decision-support Simulation Toolbox (DSST)," in Procedia CIRP, 2016, vol. 48.

[11] T. U. Pimmler and S. D. Eppinger, "Integration analysis of product decompositions," ASME 1994 Int. Des. Eng. Tech. Conf. 6th Des. Theory Methodol. Conf., no. September, pp. 343-351, 1994.

[12] W.-H. Chung, G. Okudan, and R. A. Wysk, "Modular design to optimize product life cycle metrics in a closed-looped supply chain," Proc. 2011 Ind. Eng. Res. Conf. T. Doolen E. Van Aken, eds., 2011.

[13] S. Yu, Q. Yang, J. Tao, X. Tian, and F. Yin, "Product modular design incorporating life cycle issues - Group Genetic Algorithm (GGA) based method," J. Clean. Prod., vol. 19, no. 9-10, pp. 1016-1032, 2011.

[14] Y. Garbatov, M. Ventura, T. Georgiev, P., Damyanliev, and I. Atanasova, "Investment cost estimate accounting for shipbuilding constraints," in Maritime Transportation and Harvesting of Sea Resources, Guedes Soares, C. \& Teixeira A.P. (Eds.), 2017, pp. 913 920.

[15] E. Blanco-Davis, F. del Castillo, and P. Zhou, "Fouling release coating application as an environmentally efficient retrofit: a case study of a ferry-type ship," Int. J. Life Cycle Assess., vol. 19, no. 10, pp. 17051715, Oct. 2014. 